\title{
Multidrug Resistance (MDR): A Widespread Phenomenon in Pharmacological Therapies
}

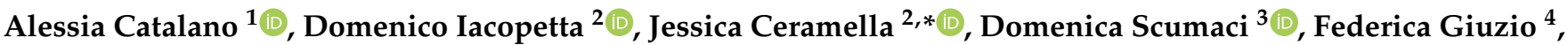

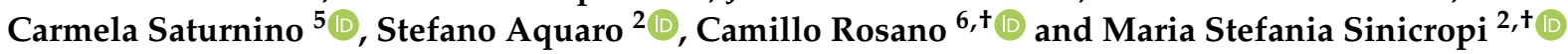

1 Department of Pharmacy-Drug Sciences, University of Bari “Aldo Moro", 70126 Bari, Italy; alessia.catalano@uniba.it

2 Department of Pharmacy, Health and Nutritional Sciences, University of Calabria, 87036 Arcavacata di Rende, Italy; domenico.iacopetta@unical.it (D.I.); stefano.aquaro@unical.it (S.A.); s.sinicropi@unical.it (M.S.S.)

3 Research Center on Advanced Biochemistry and Molecular Biology, Department of Experimental and Clinical Medicine, Magna Græcia University of Catanzaro, 88100 Catanzaro, Italy; scumaci@unicz.it

4 International PhD Programme 'Sciences', Department of Science, University of Basilicata, Viale dell'Ateneo Lucano n. 10, 85100 Potenza, Italy; federica.giuzio@unibas.it

5 Department of Science, University of Basilicata, 85100 Potenza, Italy; carmela.saturnino@unibas.it

6 Proteomics and Mass Spectrometry Unit, IRCCS Policlinico San Martino, Largo Rosanna Benzi, 10, 16132 Genoa, Italy; camillo.rosano@hsanmartino.it

* Correspondence: jessica.ceramella@unical.it; Tel.: +39-098-449-3200

+ These authors contributed equally to this work.

check for

updates

Citation: Catalano, A.; Iacopetta, D.; Ceramella, J.; Scumaci, D.; Giuzio, F.; Saturnino, C.; Aquaro, S.; Rosano, C.; Sinicropi, M.S. Multidrug Resistance (MDR): A Widespread Phenomenon in Pharmacological Therapies. Molecules 2022, 27, 616. https:// doi.org/10.3390/molecules27030616

Academic Editor: Maria José

U. Ferreira

Received: 9 December 2021

Accepted: 17 January 2022

Published: 18 January 2022

Publisher's Note: MDPI stays neutral with regard to jurisdictional claims in published maps and institutional affiliations.

Copyright: (C) 2022 by the authors. Licensee MDPI, Basel, Switzerland. This article is an open access article distributed under the terms and conditions of the Creative Commons Attribution (CC BY) license (https:// creativecommons.org/licenses/by/ $4.0 /)$.

\begin{abstract}
Multidrug resistance is a leading concern in public health. It describes a complex phenotype whose predominant feature is resistance to a wide range of structurally unrelated cytotoxic compounds, many of which are anticancer agents. Multidrug resistance may be also related to antimicrobial drugs, and is known to be one of the most serious global public health threats of this century. Indeed, this phenomenon has increased both mortality and morbidity as a consequence of treatment failures and its incidence in healthcare costs. The large amounts of antibiotics used in human therapies, as well as for farm animals and even for fishes in aquaculture, resulted in the selection of pathogenic bacteria resistant to multiple drugs. It is not negligible that the ongoing COVID-19 pandemic may further contribute to antimicrobial resistance. In this paper, multidrug resistance and antimicrobial resistance are underlined, focusing on the therapeutic options to overcome these obstacles in drug treatments. Lastly, some recent studies on nanodrug delivery systems have been reviewed since they may represent a significant approach for overcoming resistance.
\end{abstract}

Keywords: multidrug resistance; antimicrobial resistance; bacterial resistance; MDR; AMR; bacteria; antibiotics; anticancer agents

\section{Introduction}

The development of simultaneous resistance to multiple drugs, with varying chemical structures and targets, is a major obstacle to effective cancer therapy [1,2]. Multidrug resistance (MDR) is a kind of acquired resistance of microorganisms and cancer cells to chemotherapic drugs that are characterized by different chemical structures and different mechanisms of action. MDR is the consequence of the overexpression of a variety of proteins that extrude the chemotherapic from the cell, lowering its concentration below the effective one. MDR in cancer treatment is responsible for tens of thousands of deaths per year and can be conferred by a number of transporters that pump drugs out of cells as, for instance, the adenosine triphosphate binding cassette (ABC) pumps. They can translocate a wide variety of substrates, including amino acids, peptides, ions, sugars, toxins, lipids, and drugs, and are implicated in several serious human diseases, including cystic fibrosis (CF) and several disorders of the immune system [3]. The ABC transporter family is a protein superfamily with 49 different members categorized by gene sequence and structural 
similarities. These ABC transporter families, expressed in various tissues such as the liver, intestine, kidney, and brain, are divided into seven subfamilies (ABCA to ABCG) based on their gene structure, amino acid sequence, domain organization, and phylogenetic analysis. Of these, at least 11 ABC transporters including P-glycoprotein (P-GP/ABCB1), multidrug resistance-associated proteins (MRPs/ABCCs), and breast cancer resistance protein (BCRP/ABCG2) are involved in multidrug resistance (MDR) development [4]. The human $170 \mathrm{kDa}$-glycoprotein (P-gp, also referred to as multidrug resistance protein 1, MDR1, or ABCB1 or MDR1), the $190 \mathrm{kDa}$ multidrug resistance-associated protein 1 (MRP1 or $\mathrm{ABCC} 1$ ), and the $70 \mathrm{kDa}$ breast cancer resistance protein (BCRP or ABCG2) can transport diverse classes of amphipathic drug molecules. These three drug transporter pumps work through well-characterized mechanisms of MDR, knowledge of which has been exploited to find a winning approach to contrast the multidrug resistance, which is a significant hurdle in current cancer treatments and antimicrobial therapies. Thus, the inhibition of drug efflux pumps, such as P-gp, MRP1, and BCRP, has been pursued by several researchers. For instance, $\mathrm{P}$-gp inhibition-based strategies for modulating pharmacokinetics of anticancer drugs have been recently reviewed [5]. The use of natural products has been proposed also as an alternative choice for P-gp inhibition [6]. Recently, the ABC superfamily has been classified into distinct types, I-VII, based on their transmembrane domain (TMD) fold [7]. Besides, bacteria can show resistance to one or more classes of antimicrobials and, on this base, they can be classified into: multidrug-resistant bacteria (i.e., resistant to three or more classes of antimicrobials), extensively drug resistant (i.e., resistant to all but one or two classes) or pandrug-resistant (i.e., resistant to all available classes). Antimicrobial resistance (AMR) to antibiotics is a growing global problem $[8,9]$, which led to failure of even the most recent types of effective antibiotics [10] ensuring the need of a new molecule arsenal could no longer be postponed [11]. The ongoing Coronavirus Disease 2019 (COVID-19) pandemic and the lack of an effective therapeutic protocol could further contribute to AMR [12]. Indeed, with the massive, and sometimes inappropriate, use of antibiotics to treat COVID-19 and flu symptoms, AMR threat remains significant [13]. However, the relationship between COVID-19 and AMR is not clear. Guisado-Gil et al. (2020) [14] provided quantitative data about the pandemic effect on antimicrobial consumption, studying the impact of the COVID-19 pandemic in a tertiary care Spanish hospital with an active ongoing antimicrobial stewardship program (ASP). For a 20 week period, they monitored antimicrobial consumption, incidence density, and crude death rate per 1000 occupied bed days of candidemia and multidrug-resistant (MDR) bacterial bloodstream infections (BSI), and found that no change in the global trend of incidence of hospital-acquired candidemia and MDR bacterial BSI was observed (+0.5\% weekly; $p=0.816$ ). Tiri et al. (2020) [15] instead verified the bimonthly incidence of Carbapenem-Resistant Klebsiella pneumoniae (CR-Kp) (CRE) colonization patients and the incidence of CRE acquisition in an intensive care unit (ICU) during the period of January 2019 to June 2020. In Italy the infections due to antibiotic-resistant bacteria have largely attributed to CRE. The incidence of CRE acquisition went from $6.7 \%$ in 2019 to $50 \%$ in March-April 2020, despite the great attention and the training of all staff on infection control measures in the COVID-19 era. Moreover, drug repositioning, which consists of identifying and developing new uses for existing drugs, may represent a valid strategy for overcoming MDR and AMR [16,17]. The use of multi-target drugs with known toxicity profiles also proved to be a promising alternative for the treatment of bacterial infections and cancer $[18,19]$. Recently, nanomedicine, which represents a promising approach to improving drug efficacy and minimizing adverse effects, also turned out to be very useful in overcoming cancer drug resistance $[20,21]$.

\section{Efflux Pump System Mechanisms}

Among the several mechanisms that induce antibiotic resistance, drug extrusion by the drug efflux pumps represents an important cause of MDR. Reduction in intracellular drug accumulation by increasing efflux of drugs and overexpressing the drug transporters 
has been associated with clinically relevant drug resistance. This represents the principal mechanism for the development of resistance to tetracyclines, erythromycin, and fluoroquinolones. It is also the main mechanism of resistance in cancer chemotherapy. Generally, the efflux pump systems are different in prokaryotic and eukaryotic organisms, even if some of their classes are able to mediate resistance in both the organisms [22]. The prokaryotic efflux pumps are divided into six classes, while the eukaryotic ones are divided into five groups. However, the ATP- binding cassette (ABC) efflux pumps are the major efflux pumps involved in multidrug resistance. The 48 human $A B C$ transporter genes are classified into seven subfamilies (namely from ABCA to ABCG) [23]. Among them, P-glycoprotein is a well-known protein associated with multi-drug resistance. It belongs to the human ABCB (MDR/TAP) family and is also known as ABCB1 or MDR1 P-gP [24]. Structurally, $\mathrm{ABC}$ transporters are characterized by the presence of four domains consisting of two cytoplasmic nucleotide-binding domains (NBDs) that bind and hydrolyze ATP and two TMDs that identify and transport substrates [25]. In physiological conditions, $\mathrm{ABC}$ transporters control cellular levels of hormones, lipids, ions, xenobiotics, and other molecules by carrying them across cell membranes and are expressed in organs involved in elimination of these molecules as the kidney, liver, and epithelial tissues, and so on [26]. Among the $48 \mathrm{ABC}$ transporters, some bind a wide range of substrates. Some of them also have the potential to transport anticancer or antimicrobial drugs, conferring drug resistance [27] Generally, $A B C$ transporters pump the substrates against a chemical gradient, a process that necessitates ATP hydrolysis as a driving force. Under physiological conditions, $A B C$ transporters operate in a single direction, even if, under certain conditions, the drug efflux pumps could be reversible. Several mechanisms of ABC transporter have been proposed, such as alternating site, the switch, and the constant contact models. However, it seems that all these models share common phases: first, the NBD dimerization ATP dependent and then the substrates binding to the TMD and its switching between outwardand inward-facing conformations [28]. A complete understanding of the mechanisms of drug transporters and the development of efflux pump inhibitors are crucial for promising anti-drug resistance solutions.

\section{MDR in Cancer}

Chemoresistance is thought to be the cause of mortality in more than $90 \%$ of patients with advanced cancer [29]. The first-line therapy is often followed by the proliferation of a small number of survived cancer cells that leads to the development of a secondary tumor that is insusceptible to the initial set of drugs. This may cause tumor progression after stabilization or significant regression because chemotherapy, which was successful at the first stage, becomes ineffective. Chemoresistance is also associated with metastases [30] and MDR occurs frequently after long-term chemotherapy, resulting in refractory cancer and tumor recurrence. Another important consideration is that cancer cells with acquired MDR often become cross-resistant to structurally unrelated chemotherapeutic drugs. Numerous cellular and non-cellular pathways have been proposed as theoretical mechanisms behind MDR, such as decreased uptake of water-soluble drugs, increased enzyme level of xenobiotic metabolism (e.g., glutathione-S-transferase), various changes in cells that affect the ability of cytotoxic drugs to kill them, and removal of hydrophobic drugs from cells due to increased energy-dependent efflux (Figure 1) [31]. ABC transporters are a superfamily of membrane proteins mediating MDR mechanisms in multiple types of cancers [32], as they are able to translocate hydrophobic drugs and lipids from the inner to the outer leaflet of the cell membrane. Among the ABC transporters involved in MDR, P-gp (MDR1, ABCB1) and MRP can be overexpressed in malignant cells and their activity results in lack of intracellular levels of the drug necessary for an effective therapy [33]. P-gp is the best-characterized efflux pump that mediates MDR in cancer [34], which targeting represents an interesting approach for combating multidrug resistance [23]. Subcellular expression of P-glycoprotein (P-gp) may play an essential role in multidrug resistance (MDR) in many cancers such as breast cancer cells [35], human colorectal cancer 
cells [36], ovarian cancer cells [37], human lung cancer [38,39], and others. Human ABCB1 transporter was the first recognized $A B C$ transporter: its overexpression in cancer cells reduces the concentration of drugs in the cell and allows it to develop resistance to a number of chemotherapic drugs (Table 1), such as taxanes (paclitaxel), vinca alkaloids (vinblastine), and anthracyclines (daunorubicin) [40]. ABCB1 is a $170 \mathrm{kDa}$ membrane transporter that is ubiquitously expressed in the kidney, intestine, brain, and placenta. Clinical applications, exploiting the combination of an ABCB1 modulator and an anticancer drug, have been investigated as a possible strategy to overcome ABCB1-mediated drug efflux for a long time [41]. Interestingly, some studies reveal the potential role of melatonin in chemotherapeutic synergy for countering MDR. Melatonin has been reported to have an influence on the P-gp expression, increasing the chemotherapy sensitivity of colon cancer cells. In particular, the authors examined the effect of melatonin on LoVo colon cancer cells' resistance to doxorubicin. They found that some concentrations of MLT and DOX increased the percentage of cells expressing P-gp [42]. As explanatory example, epirubicin is a first-line chemotherapeutic drug for the clinical treatment of diffuse large $B$ cell lymphoma (DLBCL), but the overexpression of MDR transporter proteins, especially P-gp, determines its ineffectiveness [43]. The contemporaneously use of melatonin has been demonstrated to downregulate the expression of P-gp, ultimately sensitizing DLBCL cells to epirubicin that suppresses their growth $[43,44]$. Few developed inhibitors of P-gp have been approved for use in cancer therapy because of a lack of significant clinical efficacy, or concerns about their clinical safety. A new emerging class is represented by the antimicrobial peptides, including naturally occurring peptides as well as their synthetic derivatives that have the ability to respond to infections, receiving attention to make resistant strains sensitive to existing drugs [45]. Recently, the antimicrobial peptide XH-14C was suggested in combination with conventional anticancer agents as a novel strategy for cancer treatment. It was found that $\mathrm{XH}-14 \mathrm{C}$ reverse $\mathrm{ABCB} 1-$ mediated MDR, enhancing the intracellular accumulation of the paclitaxel-an ABCB1 substrate-drug-by directly inhibiting the efflux function of ABCB1 without affecting the transporter's expression and cellular localization [46]. Another important member of the $\mathrm{ABC}$ transporters is the $\mathrm{ABC}$ transporter subfamily $\mathrm{G}$ member 2 (ABCG2), which is also named BCRP. It is present in the apical membranes of many epithelial cells and tissues, including lung, gut, intestine, liver, breast, placenta, hematopoietic stem cells, and especially in the blood-brain barrier. It is overexpressed in many solid tumors as well as acute myeloid leukemia (AML) and acute lymphocytic leukemia (ALL). Dysregulated ABCG2 overexpression is linked with poor prognosis in several cancer types with particularly low survival in AML patients. High ABCG2 expression in cancer cells results in resistance to a wide spectrum of chemotherapeutic agents, including mitoxantrone, topotecan, SN-38, and doxorubicin [47]. Numerous studies have shown that the tumors expressing high levels of ABCG2 are refractory to anticancer drugs [48]. Recent studies suggest a synergistic effect of Venetoclax (Venclexta, Venclyxto, ABT-199, GDC-0199, RG7601) with certain chemotherapeutic agents for the treatment of MDR cancers. Venetoclax is a potent and selective Bcl-2 inhibitor, approved by the FDA in 2016 for the treatment of patients with chronic lymphocytic leukemia (CLL) with 17p deletion. Bcl-2 represents an antiapoptotic protein playing an important role in tumorigenesis and chemoresistance, which is often overexpressed in hematopoietic malignancies. Venetoclax was demonstrated to enhance the efficacy of ABCG2-substrate anticancer agents by directly inhibiting ABCG2-ATPase activity, blocking the efflux function of wild-type ABCG2, and therefore increasing the intracellular accumulation of the chemotherapeutic drugs. A docking simulation suggested that Venetoclax could bind the drug-binding pocket and ATP-binding site of ABCG2, impeding its efflux activity [49]. The development of novel reversal agents that could inhibit the efflux functions of ABC transporters is an urgent need that could bring some advantages in chemotherapy. Several new potential drugs for the treatment of cancer are under study [50-52] and the complexes with transition metals represent an important alternative way to combat MDR [53-56]. The modulation of reactive oxidative species (ROS) may represent another strategy to kill MDR 
cancer cells that are mechanistically diverse $[57,58]$. In cancer cells, ROS are involved in the regulation and induction of apoptosis, thereby they play a central role in modulating cancer cells proliferation, survival, and drug resistance. The ROS levels and the activity of scavenging/antioxidant enzymes in drug resistant cancer cells are higher than those found in non-MDR cancer and normal cells [59]. Therefore, MDR cancer cells may be more susceptible to alterations in ROS levels, thus compounds able to modulate ROS levels can exert a sensitizing effect and enhance the response to certain chemotherapeutic drugs. In this context, natural products, such as Salvia fruticosa Mill. and pomegranate Akko peel, thanks to their demonstrated antioxidant and antiproliferative activities [60,61], could represent a valid approach useful for overcoming cancer resistance. Indeed, it is noteworthy that the polyphenol resveratrol has been proposed as a MDR reversion molecule in breast cancer and its derivatives exhibited good anticancer properties, inducing apoptosis [62,63]. In addition, the autophagy pathways seem to be involved in the development of MDR [64]. This is a self-degradative system that arises during the treatment of sensitive and MDR cancer and has a double face in MDR tumors, as it participates in the development of MDR and protects cancer cells from chemotherapeutics. However, some results indicate that autophagy induced by anticancer drugs may kill MDR cancer cells for which apoptosis pathways are inactive or, alternatively, determine the activation of apoptosis signaling pathways, thus facilitating MDR reversal [65]. Another way to combat MDR exploits the inhibition of P-gp and p53-Mdm2 protein-protein interaction (PPI), since the p53-Mdm2 pathway is compromised in more than $50 \%$ of all human cancers. p53-Mdm2 PPI inhibitors were suggested as a promising platform for the development of multitarget drugs that can overcome tumor resistance by inhibiting the P-gp activity [66].

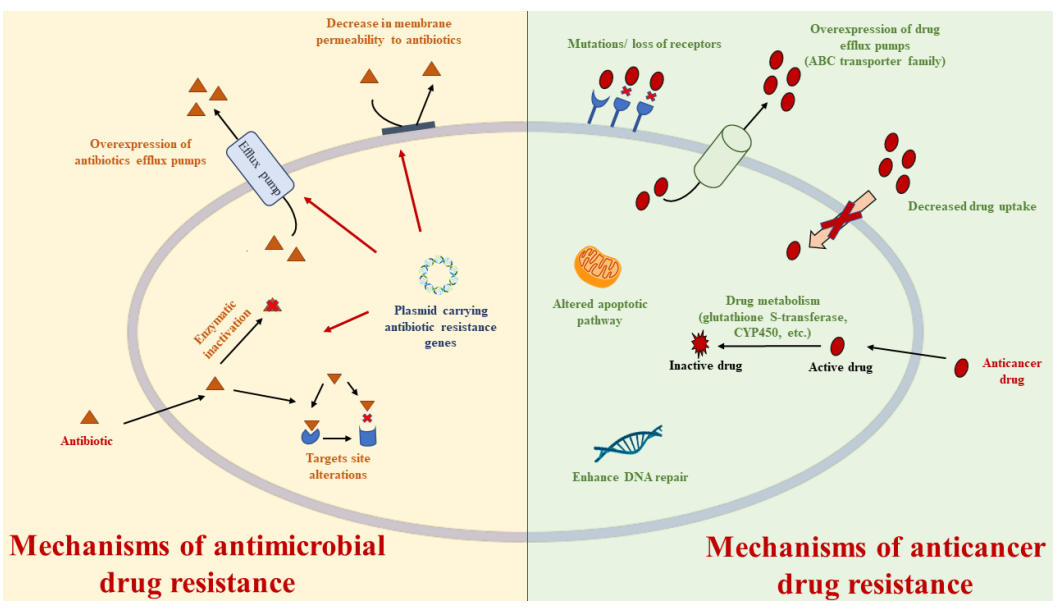

Figure 1. Mechanisms of antimicrobial and anticancer drug resistance.

Table 1. Structure of drugs mentioned in the text.

Formula Name


Table 1. Cont.

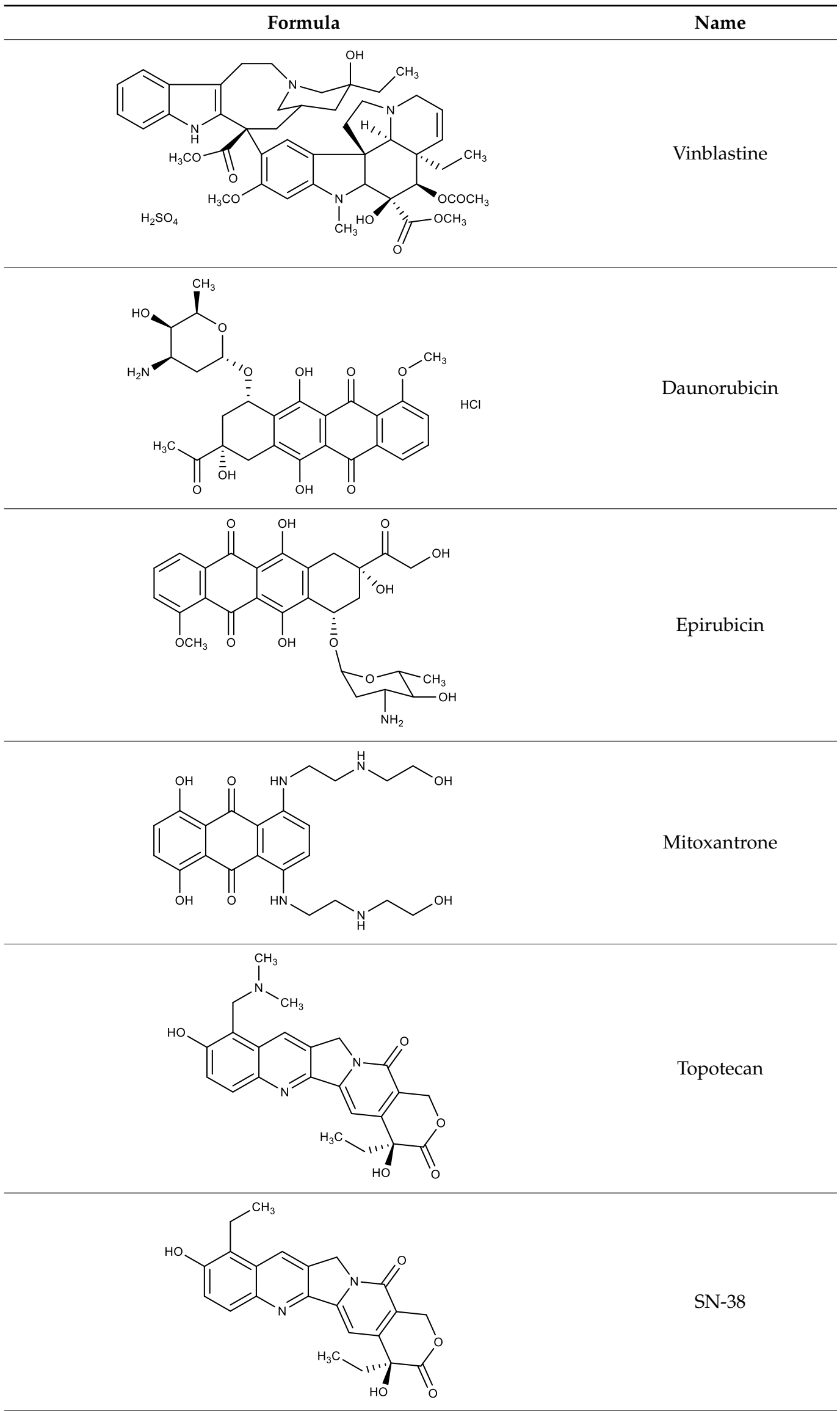


Table 1. Cont.

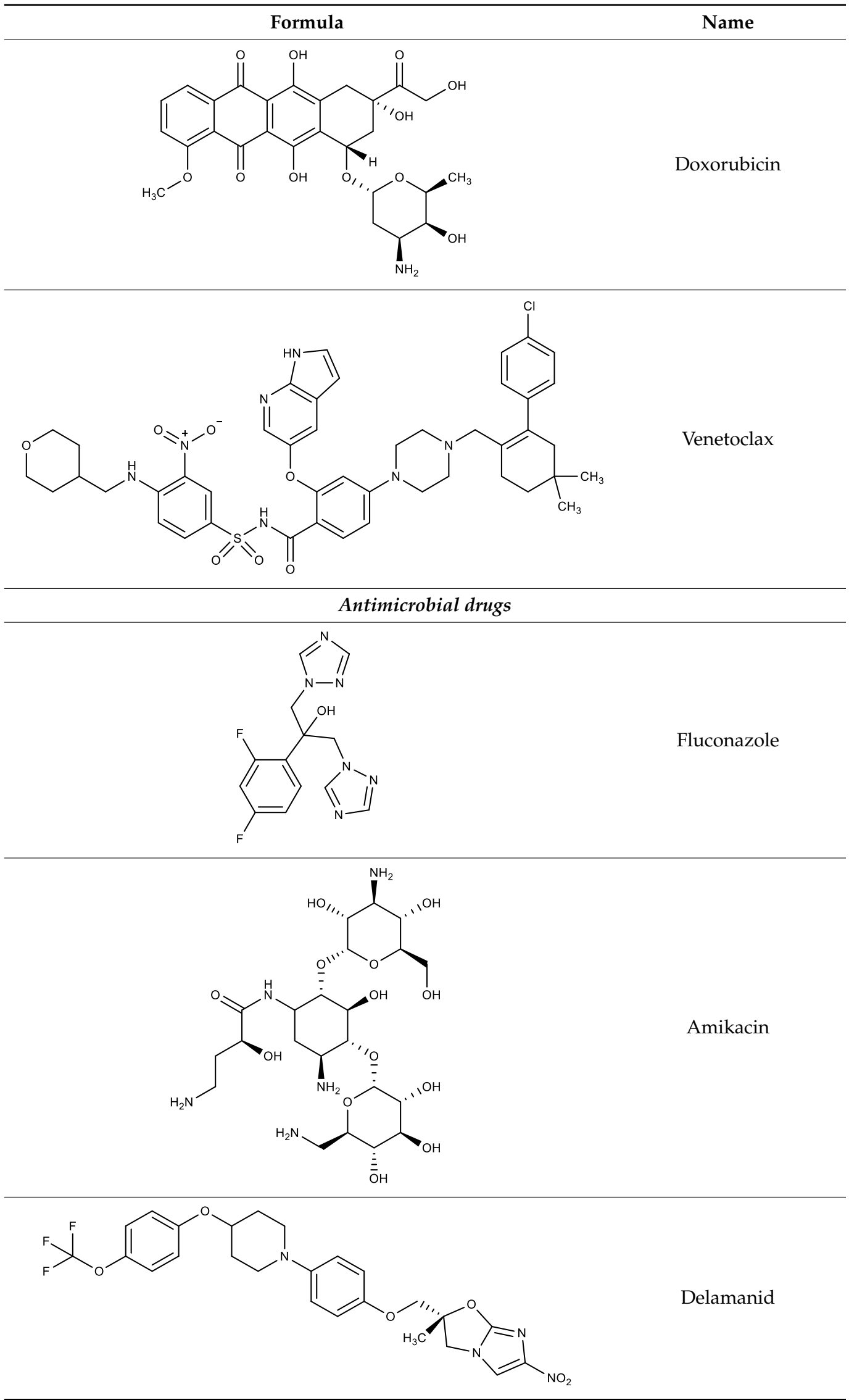


Table 1. Cont.

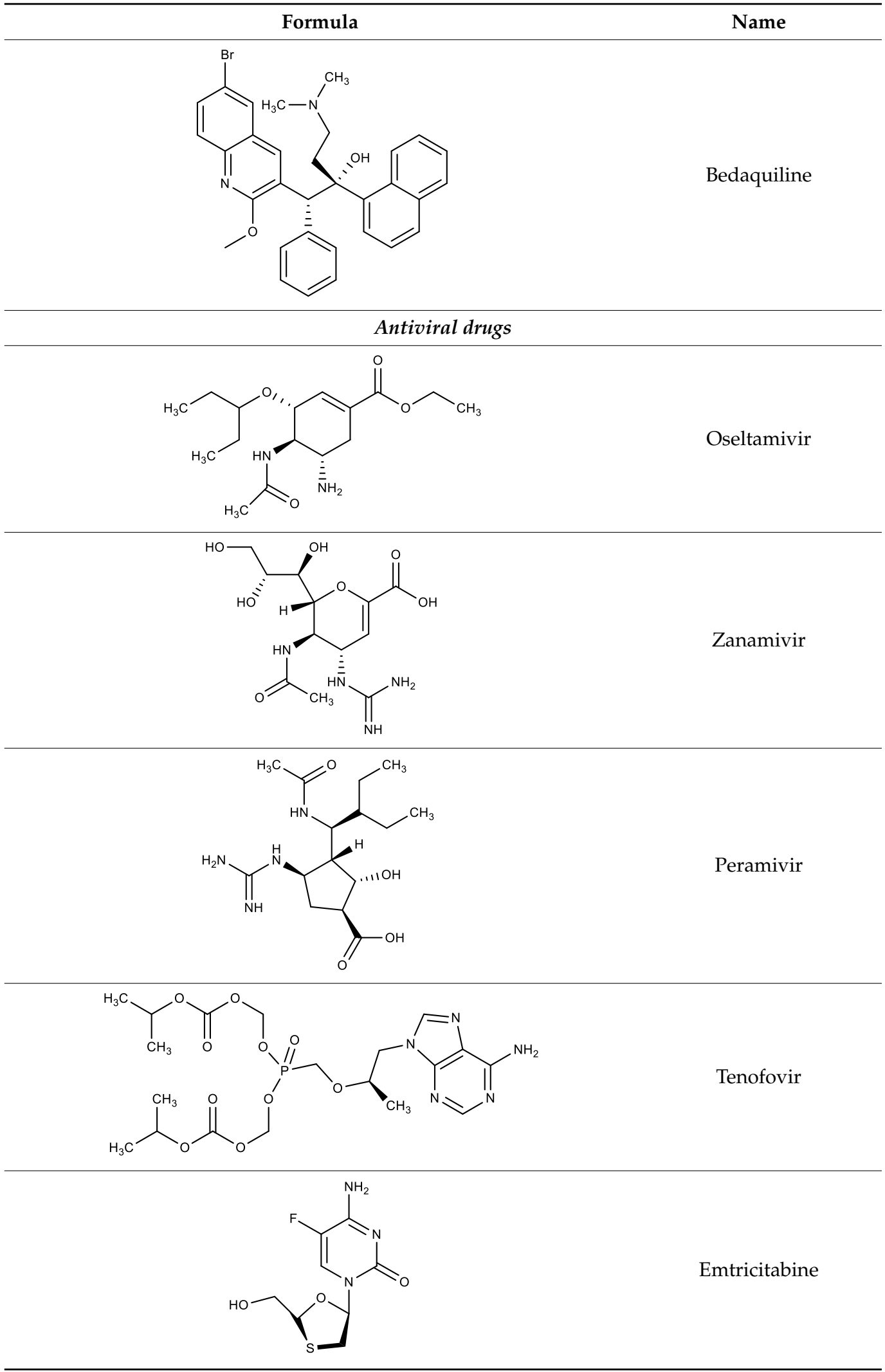


Table 1. Cont.

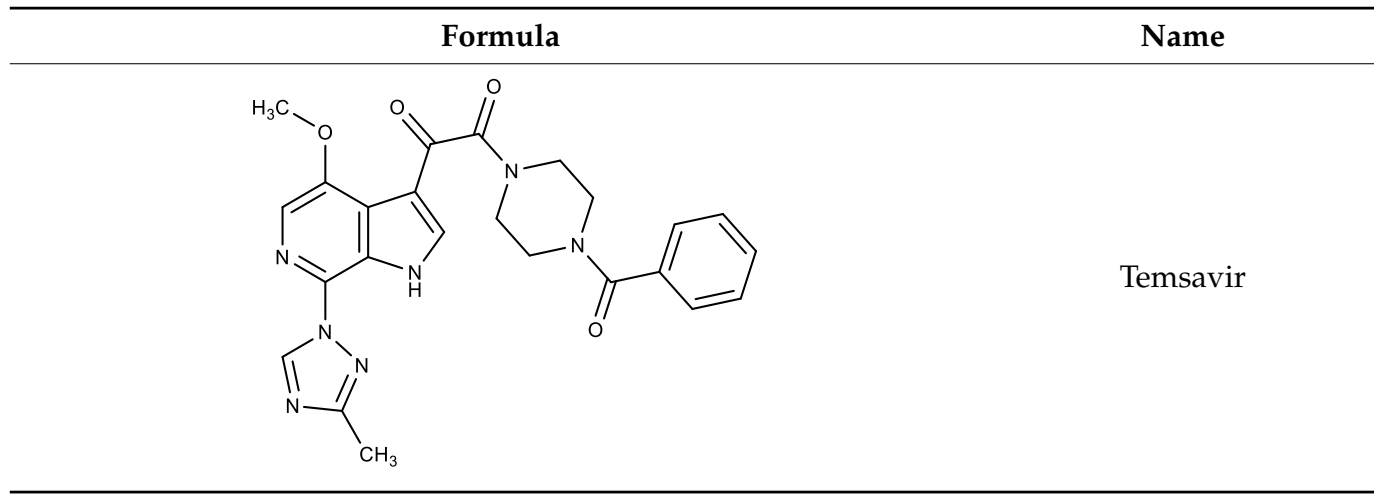

\section{MDR and Antimicrobials}

The rapid development of MDR bacteria due to the improper and overuse of antibiotics, together with their ineffective performance, against the difficult-to-treat biofilmrelated infections (BRIs) have urgently called for alternative antimicrobial agents and strategies to combat bacterial infections [67]. MDR in bacteria may be generated by several mechanisms. First, bacteria may accumulate multiple genes-each coding for resistance to a single drug-within a single cell, and this accumulation typically occurs on resistance R-plasmids. Moreover, multidrug resistance may also occur due to the increased expression of genes that code for multidrug efflux pumps, extruding a wide range of drugs. Finally, MDR can be developed by enzymatic inactivation of the drugs through their degradation or by transfer of a chemical group to them. Some drugs can be inactivated by hydrolyzation (penicillin, tetracycline, etc.). Drug inactivation by transfer of a chemical group commonly occurs through the transfer of acetyl, phosphoryl, and adenyl groups [68]. Antimicrobial resistance of non-fermenting Gram-negative bacteria is increasingly recognized as an urgent healthcare threat and has been reported from different areas all over the world [69]. MDR may also refer to clinically important multi-resistant Gram-positive bacteria, such as Enterococcus faecium and E. faecalis [70]. In-depth studies on bacteria could be essential to fully understand the physiological functions of these microbes and consequently overcome problems related to MDR [71,72]. The search for new antimicrobial agents that may overcome AMR is a very important goal to pursue $[73,74]$. Recent literature describes many compounds with antimicrobial activity [75-77]. Antimicrobial peptides (AMPs), owing to their compelling antimicrobial activity against MDR bacteria and BRIs without causing bacteria resistance, are promising alternative antimicrobial agents to combat MDR [78]. For instance, the antibiotic-resistant Pseudomonas aeruginosa infections are the primary cause of mortality in people with CF [79]. The antimicrobial peptide DP7, designed in silico, possesses a broad-spectrum antimicrobial activity by inhibiting the growth of clinical $P$. aeruginosa strains and reducing biofilm formation. In acute lung infection, it exhibited a $70 \%$ protection rate and reduced bacterial colonization by $50 \%$ in chronic infection. It mainly suppressed gene expression involving lipopolysaccharide (LPS) and outer membrane proteins and disrupted cell-wall structure [80]. Recently, a great deal of effort has been directed towards the problem of fighting against biofilm formation by bacteria. A biofilm is closed layer of bacteria that are adherent to each other, forming a polymer matrix consisting of polysaccharide, protein, and DNA. Bacterial biofilms increase tolerance to antibiotics and disinfectant and their survival is ensured by chromosomal beta-lactamase, upregulated efflux pumps, and mutations in antibiotic target molecules in bacteria [81]. Multidrug-resistant Enterobacterales (MDR-E) strains to carbapenems and other extendedspectrum- $\beta$-lactam may cause colonization or infection in solid-organ transplantation (SOT) recipients with mortality rates ranging from 5 to 20\% [82]. A phage therapy has been recently proposed. Phages, viruses that infect bacteria, are environmentally ubiquitous, host-specific, and effective at infecting MDR bacterial strains $[83,84]$. The phage proposed therapy employs OMKO1, a lytic bacteriophage (family Myoviridae) of P. aeruginosa that 
utilizes the outer membrane porin $\mathrm{M}$ (OprM) of the multidrug efflux systems MexAB and MexXY as a receptor-binding site. This may represent a new approach to phage therapy where bacteriophages exert selection for MDR bacteria to become increasingly sensitive to the traditional antibiotics [85]. This therapy could not only improve the clinical efficacy against MDR bacteria, but also potentially slow or reverse the incidence of antibiotic resistant bacterial pathogens [86]. Recently, mutations of the mexEF and mexR efflux pump systems in $P$. aeruginosa, due to a treatment with the antibiotic aztreonam, have been investigated in acute murine lung infection. However, literature data reported that, even though mexR mutations are common in CF [87], the frequency of mutants having both mutations is still unclear, and the murine model employed is not very similar to the chronic infections affecting people with CF [88]. Pandrug-resistant Klebsiella pneumoniae (PDR-Kp) may cause bacteremia with high mortality, especially among patients with septic shock [89]. Multidrug-resistant tuberculosis (MDR-TB) is a threat for the global TB epidemic control in adults and children and, in 2015, 10 million new cases were reported worldwide [90]. MDR-TB is defined as simultaneous resistance to rifampicin and isoniazid, the cornerstones of the treatment of drug-susceptible tuberculosis, necessitating the use of expensive and toxic second-line treatment regimens. For instance, amikacin has been used for more than 40 years, although controversy over the right dose remains [91]. Delamanid and Bedaquiline are used, also in association, in MDR-TB [92]. A WHO (World Health Organization) strategy for worldwide eradication of tuberculosis is the directly observed therapy short-course (DOTS), followed by therapy [93], and an update by the Global Tuberculosis Network has been recently reported [94]. The overexpression of drug efflux pumps belonging to the ABC superfamily is also a frequent cause of resistance to antifungals [95]. MDR in yeasts seems to be related to pleiotropic drug resistance (PDR) subfamily and major facilitator superfamily (MFS) transporters [96] even though their mechanisms remain unclear $[97,98]$. Azole resistance is a major concern for treatment of infections with Aspergillus fumigatus, a saprophytic mold that can cause a range of clinical syndromes ranging from allergic conditions to acute and chronic invasive pulmonary aspergillosis, especially in immunosuppressed patients [99]. The recent emergence of Candida auris has caused significant concerns, given its worldwide distribution and high reported incidence of antifungal resistance, moreover it has been estimated that $93 \%$ of clinical isolates exhibit increased resistance to fluconazole [100]. Recent studies about MDR in microbes regards a new type II topology of ABC transporters, the Candida drug resistance 1 and 2 proteins, Cdr1p and Cdr2p in C. albicans, and the Pleiotropic drug resistance 5 protein Pdr5p in Saccharomyces cerevisiae [101]. Finally, it is becoming recognized that resistance to antibiotics can occur either by mutations or by acquisition of resistance conferring genes via horizontal gene transfer (HGT). Multiple mechanisms of HGT are discovered: conjugation by plasmids, transduction by bacteriophages, and natural transformation by extracellular DNA allow genetic material to jump between strains and species. Thus, HGT contributes significantly to the rapid spread of resistance, even if the transmission dynamics of genes, that confer antibiotic resistance are not completely understood [102,103].

\section{MDR and Antivirals}

MDR in viruses is another serious problem of the last century and it is often related to MDR in bacteria, as happens in patients receiving treatments for MDR-TB and hepatitis $\mathrm{C}$ virus (HCV) or human immunodeficiency virus (HIV) $[104,105]$. Bacteria and other microorganisms have evolved several different resistance mechanisms, while resistance to antivirals occurs only as a result of mutations in the genes that encode antiviral target sites or antiviral drug activators [106]. Indeed, antiviral resistance usually involves amino acid substitutions in the target protein that prevent drug binding or prevent an enzyme from accepting the drug as a substrate [107]. The emergence of a multidrug-resistant pandemic influenza A (H1N1) virus was reported in 2010 in a patient treated with neuraminidase inhibitors, with a novel resistance pattern that conferred resistance to oseltamivir, zanamivir, and peramivir [108]. Moreover, studies in patients with multidrug-resistant HIV have 
been also carried out [109]. Recently, the acquisition of MDR HIV-1 infection in a patient taking pre-exposure prophylaxis with a combination tenofovir disoproxil fumarate and emtricitabine has been reported [110]. Treatment with fostemsavir, the prodrug of the HIV-1 attachment inhibitor temsavir, has been suggested as a valuable therapeutic option in heavily treatment-experienced patients harboring MDR virus, with limited therapeutic options [111]. However, new strategies for obtaining effective antivirals are needed [112]. MDR to antibiotics is a growing worldwide problem to which the ongoing COVID-19 pandemic may further contribute. With resources deployed away from antimicrobial stewardship, evidence of substantial pre-emptive antibiotic use in COVID-19 patients and indirectly, with deteriorating economic conditions fueling poverty and potentially impacting on levels of resistance, AMR threat remains significant [113]. Bork et al. (2021) [114] evaluated the effects of antibiotic use in the multidrug-resistant Gram-negative (MDRGN) acquisition among COVID-19 patients in an academic hospital. They found that MDRGN acquisition increased 3\% for every increase in positive COVID-19 tests per week. The high antibiotic utilization may have contributed to the increase in MDRGNs among COVID-19 patients, together with other factors (altered infection control practices, critical illness and prolonged hospital stay of COVID-19 patients) [114]. Ukuhor (2021) reported that various types of bacterial and fungal infections occur in patients with COVID-19 with some resistant to antimicrobials that are associated with significantly worse outcomes and deaths [115]. In another study of Lobie et al. (2021) [115] is reported that some disinfectants, such as sanitizers, contain genotoxic chemicals that damage microbial DNA, activating error-prone DNA repair enzymes, which can lead to mutations that induce antimicrobial resistance. On the other hand, it is fair to report a retrospective study that demonstrated a reduction in MDR bacterial infections during the COVID-19 pandemic. The authors assess that a high level of preventive measures could help tackle an important health problem such as that of the spread of MDR bacteria [116]. Moreover, increased hand hygiene, decreased international travel, and decreased elective hospital procedures may reduce AMR pathogen selection and spread in the short term [117]. However, the lack of studies supporting one hypothesis or the other one makes any deduction far from a sound scientific interpretation.

\section{Nanocarriers}

Nanotechnology-based chemotherapies are gaining increasing interest in cancer drug treatment, with particular attention to MDR cases. Indeed, nanocarriers such as liposomes, polymeric micelles, metallic nanoparticles, or dendrimers all contribute to co-delivering different chemotherapeutics, and may represent an interesting strategy to increase the drug selectivity, diminish the onset of undesired side effects and, last but not least, overcome the resistance in cancer $[118,119]$. Increasing efforts in the development of new materials able to confer selectivity towards cancerous tissues to antineoplastic compounds is essential. The selective accumulation of chemotherapeutics in the tumor region can be obtained with a combination of active and passive targeting that can further help to reduce the toxic effects to healthy tissues/organs and to overcome the resistance phenomena [120]. Gold nanoparticles (AuNPs) have attracted scientific interests among various nanocarriers developed for use in nanomedicines and have been actually used to overcome cancer MDR against chemotherapeutic agents in cancer cells [121,122]. As example, Doxorubicin was coupled with PEGylated AuNPs of $5 \mathrm{~nm}$ through enzyme-cleavable disulfide linkage or conjugated to AuNPs through a polyethylene glycol (PEG) spacer using acid labile hydrazine linkage [122]. Generally, the modification of biological molecules by covalent conjugation with PEG, PEGylation, improves drug solubility and decreases immunogenicity. PEGylation also increases drug stability and the retention time of the conjugates in blood, resulting in an improvement in the pharmacokinetic behavior of the drug [123]. The two obtained nanocargo systems were investigated for reversing MDR in HepG2-R MDR cell line and breast cancer MCF-7 / ADR cell line, respectively. The drug anticancer activity was improved significantly in the MDR cancer cells upon conjugating to the designed AuNPs in both cases [124]. The size of AuNPs is crucial and the critical size for overcoming MDR was 
identified to be between 4.1 and $5.4 \mathrm{~nm}$ [125]. The use of nanomaterials for antibacterial activity, the type of nanomaterials, the strategies to tackle their toxicity, as well as their limits, have been recently reviewed. Generally, the nanoparticles (NPs) can overcome the common resistance mechanisms, such as enzymatic inactivation or modification of the active site, diminished cell permeability or increased activity/expression of efflux pumps, allowing the antibacterial activity. In addition, if NPs are conjugated with antibiotics, they show synergistic effects against inhibiting the biofilm formation in multidrug-resistant organisms [126-128]. The employment of NPs is also widely studied to overcome multidrug resistance for the treatment of methicillin-resistant Staphylococcus aureus (MRSA), a Gram-positive bacterium responsible for many complicated infections, including those affecting skin and soft tissue, bone and joints together with pneumonia, osteomyelitis, and infective endocarditis [129]. Nanodrug delivery systems have great potential in the translation of MRSA treatments towards better therapeutic outcomes and represent a significant approach for overcoming bacterial MDR. Finally, the nano-biomaterials have been suggested for the treatment of MDR-TB [130]. AMPs-based nano-formulations have significantly improved the therapeutic effects of AMPs in various bacterial infections models, including bloodstream (specifically sepsis), pulmonary, chronic wound, and gastrointestinal infections, by ameliorating their hydrolytic stability, in vivo half-life, and solubility, as well as reducing the cytotoxicity and hemolysis [131]. In summation, the most promising perspective on using nanotechnology resides in the possibility to wrap several types of drugs in nanocarriers and/or connect even different chemical substituents and specific substances on their surface to achieve optimal targeting, increase the drug stability and selectivity, and decrease the risk of undesired effects. Unfortunately, some disadvantages should be considered, because the in vivo NPs pharmacokinetics and excretion are not yet fully understood and require further study.

\section{Summary}

The MDR phenomenon represents a serious medical problem and constitutes a major challenge to the treatment of infectious diseases and cancer and the development of novel therapeutics. MDR in cancer cells is mainly due to drug efflux transporters, particularly those belonging to the ABC superfamily. Different treatments of choice are available for the MDR, among which the most common are represented by the inhibition of P-gp, MBR, and ABCG2, and the modulation of ROS. However, given the adverse effects of these drugs, investigating and establishing effective and non-toxic drugs to reverse MDR in cancers has become a pressing need. Moreover, the increasing prevalence and severity of MDR bacterial infections has necessitated novel antibacterial strategies. Amongst them, nanotechnology has proved to be a promising tool for the whole scientific community by creating new therapies for advanced treatment of various diseases. The design of nanosystems for codelivering anticancer agents may represent a new challenge to combat resistance, although further in vivo studies regarding their pharmacokinetics and metabolism are necessary.

Author Contributions: Conceptualization, A.C. and M.S.S.; writing-original draft preparation, D.I. and J.C.; methodology, D.S. and F.G.; validation, and J.C. and C.S.; writing-review and editing, A.C. and S.A.; supervision, C.R. and M.S.S. All authors have read and agreed to the published version of the manuscript.

Funding: This research received no external funding.

Institutional Review Board Statement: Not applicable.

Informed Consent Statement: Not applicable.

Data Availability Statement: Not applicable.

Conflicts of Interest: The authors declare no conflict of interest. 


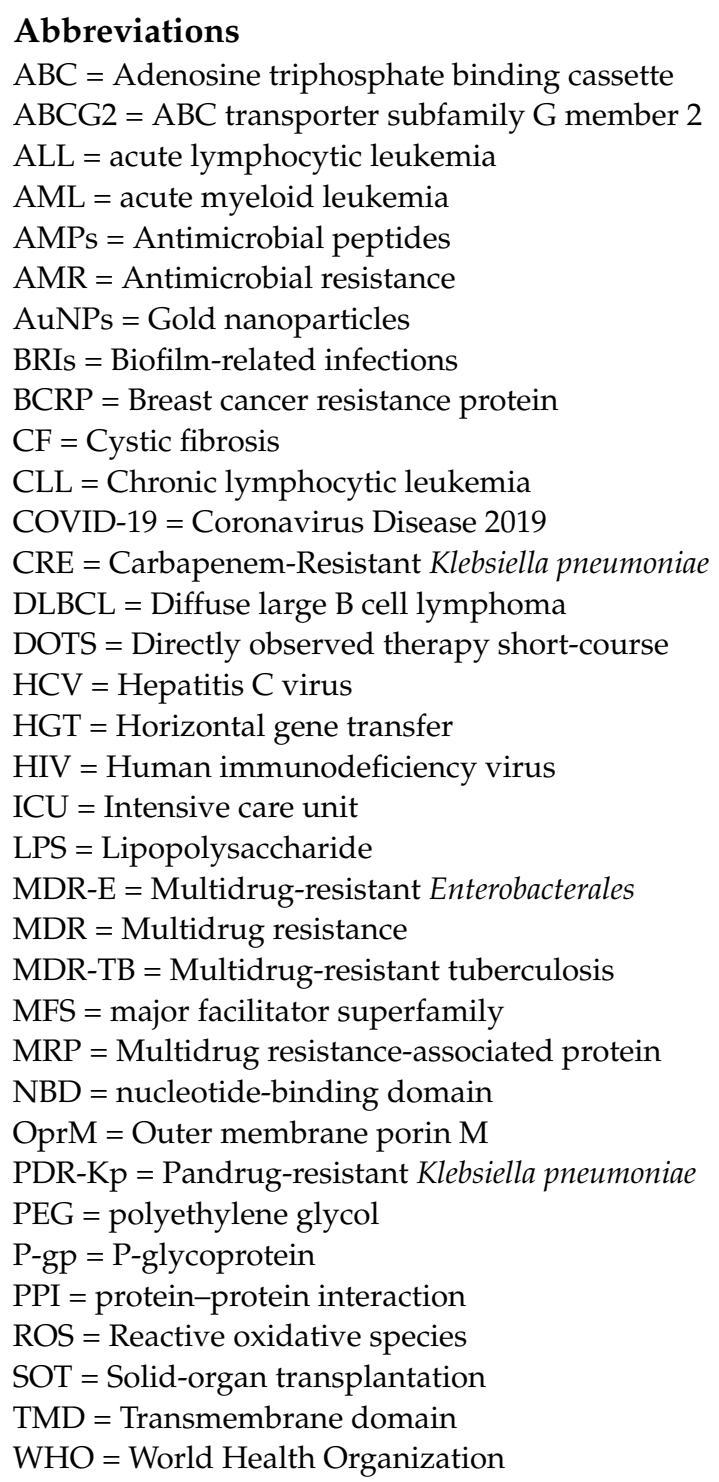

\section{References}

1. Wang, J.; Seebacher, N.; Shi, H.; Kan, Q.; Duan, Z. Novel strategies to prevent the development of multidrug resistance (MDR) in cancer. Oncotarget 2017, 8, 84559-84571. [CrossRef] [PubMed]

2. Iacopetta, D.; Rosano, C.; Sirignano, M.; Mariconda, A.; Ceramella, J.; Ponassi, M.; Saturnino, C.; Sinicropi, M.S.; Longo, P. Is the way to fight cancer paved with gold? Metal-based carbene complexes with multiple and fascinating biological features. Pharmaceuticals 2020, 13, 91. [CrossRef]

3. Thomas, C.; Tampe, R. Structural and mechanistic principles of ABC transporters. Annu. Rev. Biochem. 2020, 89, 605-636. [CrossRef]

4. Liu, X. ABC Family Transporters. Adv. Exp. Med. Biol. 2019, 1141, 13-100.

5. Yang, X.; Liu, K. P-gp inhibition-based strategies for modulating pharmacokinetics of anticancer drugs: An update. Curr. Drug Metab. 2016, 17, 806-826. [CrossRef]

6. Dewanjee, S.; Dua, T.K.; Bhattacharjee, N.; Das, A.; Gangopadhyay, M.; Khanra, R.; Joardar, S.; Riaz, M.; Feo, V.D.; Zia-Ul-Haq, M. Natural products as alternative choices for P-Glycoprotein (P-gp) inhibition. Molecules 2017, 22, 871. [CrossRef]

7. Thomas, C.; Aller, S.G.; Beis, K.; Carpenter, E.P.; Chang, G.; Chen, L.; Dassa, E.; Dean, M.; Van Hoa, F.D.; Ekiert, D.; et al. Structural and functional diversity calls for a new classification of ABC transporters. FEBS Lett. 2020, 594, 3767-3775. [CrossRef] [PubMed]

8. Dadgostar, P. Antimicrobial resistance: Implications and costs. Infect. Drug Resist. 2019, 12, 3903-3910. [CrossRef]

9. Hofer, U. The cost of antimicrobial resistance. Nat. Rev. Microbiol. 2019, 17, 3. [CrossRef]

10. Cassini, A.; Högberg, L.D.; Plachouras, D.; Quattrocchi, A.; Hoxha, A.; Simonsen, G.S.; Colomb-Cotinat, M.; Kretzschmar, M.E.; Devleesschauwer, B.; Cecchini, M.; et al. Attributable deaths and disability-adjusted life-years caused by infections with antibiotic-resistant bacteria in the EU and the European Economic Area in 2015: A population-level modelling analysis. Lancet Infect. Dis. 2019, 19, 56-66. [CrossRef] 
11. Bonomo, M.G.; Giura, T.; Salzano, G.; Longo, P.; Mariconda, A.; Catalano, A.; Iacopetta, D.; Ceramella, J.; Sinicropi, M.S.; Saturnino, C. Bis-thiourea quaternary ammonium salts as potential agents against bacterial strains from food and environmental matrices. Antibiotics 2021, 10, 1466. [CrossRef]

12. Catalano, A. COVID-19: Could irisin become the handyman myokine of the 21st century? Coronaviruses 2020, 1, 32-41. [CrossRef]

13. Adebisi, Y.A.; Alaran, A.J.; Okereke, M.; Oke, G.I.; Amos, O.A.; Olaoye, O.C.; Oladunjoye, I.; Olanrewaju, A.Y.; Ukor, N.A.; Lucero-Prisno, D.E. COVID-19 and Antimicrobial Resistance: A Review. Infectious Diseases 2021, 14, 11786337211033870. [CrossRef]

14. Guisado-Gil, A.B.; Infante-Domínguez, C.; Peñalva, G.; Praena, J.; Roca, C.; Navarro-Amuedo, M.D.; Aguilar-Guisado, M.; Espinosa-Aguilera, N.; Poyato-Borrego, M.; Romero-Rodríguez, N.; et al. Impact of the COVID-19 pandemic on antimicrobial consumption and hospital-acquired candidemia and multidrug-resistant bloodstream infections. Antibiotics 2020, 9, 816. [CrossRef] [PubMed]

15. Tiri, B.; Sensi, E.; Marsiliani, V.; Cantarini, M.; Priante, G.; Vernelli, C.; Martella, L.A.; Costantini, M.; Mariottini, A.; Andreani, P.; et al. Antimicrobial Stewardship Program, COVID-19, and Infection Control: Spread of Carbapenem-Resistant Klebsiella Pneumoniae Colonization in ICU COVID-19 Patients. What Did Not Work? J. Clin. Med. 2020, 9, 2744. [CrossRef] [PubMed]

16. Rausch, M.; Rutz, A.; Allard, P.M.; Delucinge-Vivier, C.; Docquier, M.; Dormond, O.; Dyson, P.J.; Wolfender, J.-L.; NowakSliwinska, P. Drug repurposing to identify a synergistic high-order drug combination to treat sunitinib-resistant renal cell carcinoma. Cancers 2021, 13, 3978. [CrossRef] [PubMed]

17. Parisi, O.I.; Ruffo, M.; Malivindi, R.; Vattimo, A.F.; Pezzi, V.; Puoci, F. Molecularly imprinted polymers (MIPs) as theranostic systems for sunitinib controlled release and self-monitoring in cancer therapy. Pharmaceutics 2020, 12, 41. [CrossRef] [PubMed]

18. Iacopetta, D.; Carocci, A.; Sinicropi, M.S.; Catalano, A.; Lentini, G.; Ceramella, J.; Curcio, R.; Caroleo, M.C. Old drug scaffold, new activity: Thalidomide-correlated compounds exert different effects on breast cancer cell growth and progression. ChemMedChem 2017, 12, 381-389. [CrossRef]

19. Barbarossa, A.; Catalano, A.; Ceramella, J.; Carocci, A.; Iacopetta, D.; Rosano, C.; Franchini, C.; Sinicropi, M.S. Simple thalidomide analogs in melanoma: Synthesis and biological activity. Appl. Sci. 2021, 11, 5823. [CrossRef]

20. Su, Z.; Dong, S.; Zhao, S.C.; Liu, K.; Tan, Y.; Jiang, X.; Assaraf, Y.G.; Qin, B.; Chen, Z.-S.; Sou, C. Novel nanomedicines to overcome cancer multidrug resistance. Drug Resist. Updat. 2021, 58, 100777. [CrossRef] [PubMed]

21. Liu, S.; Khan, A.; Yang, X.; Dong, B.; Ji, J.; Zhai, G. The reversal of chemotherapy-induced multidrug resistance by nanomedicine for cancer therapy. J. Control. Release 2021, 335, 1-20. [CrossRef]

22. Poole, K. Outer membranes and efflux: The path to multidrug resistance in Gram-negative bacteria. Curr. Pharm. Biotechnol. 2002, 3, 77-98. [CrossRef] [PubMed]

23. Szakacs, G.; Paterson, J.K.; Ludwig, J.A.; Booth-Genthe, C.; Gottesman, M.M. Targeting multidrug resistance in cancer. Nat. Rev. Drug Discov. 2006, 5, 219-234. [CrossRef]

24. Pohl, A.; Devaux, P.F.; Herrmann, A. Function of prokaryotic and eukaryotic ABC proteins in lipid transport. Biochim. Biophys. Acta BBA Mol. Cell Biol. Lipids 2005, 1733, 29-52. [CrossRef] [PubMed]

25. Symmons, M.F.; Bokma, E.; Koronakis, E.; Hughes, C.; Koronakis, V. The assembled structure of a complete tripartite bacterial multidrug efflux pump. Proc. Natl. Acad. Sci. USA 2009, 106, 7173-7178. [CrossRef] [PubMed]

26. Hagenbuch, B.; Gao, B.; Meier, P.J. Transport of xenobiotics across the blood-brain barrier. News Physiol. Sci. 2002, 17, 231-234 [CrossRef] [PubMed]

27. Mlejnek, P.; Kosztyu, P.; Dolezel, P.; Bates, S.E.; Ruzickova, E. Reversal of ABCB1 mediated efflux by imatinib and nilotinib in cells expressing various transporter levels. Chem. Biol. Interact. 2017, 273, 171-179. [CrossRef]

28. Wilkens, S. Structure and mechanism of ABC transporters. F1000Prime Rep. 2015, 7, 14. [CrossRef]

29. Mansoori, B.; Mohammadi, A.; Davudian, S.; Shirjang, S.; Baradaran, B. The different mechanisms of cancer drug resistance: A brief review. Adv. Pharm. Bull. 2017, 7, 339. [CrossRef] [PubMed]

30. Zheng, H.C. The molecular mechanisms of chemoresistance in cancers. Oncotarget 2017, 8, 59950-59964. [CrossRef] [PubMed]

31. Kathawala, R.J.; Gupta, P.; Ashby, C.R.; Chen, Z.-S. The modulation of ABC transporter-mediated multidrug resistance in cancer: A review of the past decade. Drug Resist. Updat. 2015, 18, 1-17. [CrossRef] [PubMed]

32. Krishna, R.; Mayer, L.D. Multidrug resistance (MDR) in cancer: Mechanisms, reversal using modulatorsof MDR and the role of MDR modulators in influencing the pharmacokinetics of anticancer drugs. Eur. J. Pharm. Sci. 2000, 11, 265-283. [CrossRef]

33. Dong, J.; Qin, Z.; Zhang, W.D.; Cheng, G.; Yehuda, A.G.; Ashby, C.R., Jr.; Chen, Z.S.; Cheng, X.D.; Qin, J.J. Medicinal chemistry strategies to discover P-glycoprotein inhibitors: An update. Drug Resist. Updat. 2020, 49, 100681. [CrossRef] [PubMed]

34. Carocci, A.; Catalano, A.; Turi, F.; Lovece, A.; Cavalluzzi, M.M.; Bruno, C.; Colabufo, N.; Contino, M.A.; Perrone, M.G.; Franchini, C.; et al. Stereoselective modulation of P-glycoprotein by chiral small molecules. ChemMedChem 2016, 11, 93-101. [CrossRef]

35. Aniogo, E.C.; George, B.P.; Abrahamse, H. Response of MCF-7 breast cancer cells overexpressed with P-glycoprotein to apoptotic induction after photodynamic therapy. Molecules 2021, 26, 7412. [CrossRef] [PubMed]

36. Aires, V.; Colin, D.J.; Doreau, A.; Di Pietro, A.; Heydel, J.-M.; Artur, Y.; Latruffe, N.; Delmas, D. P-Glycoprotein 1 affects chemoactivities of resveratrol against human colorectal cancer cells. Nutrients 2019, 11, 2098. [CrossRef] [PubMed]

37. Guo, W.; Dong, W.; Li, M.; Shen, Y. Mitochondria P-glycoprotein confers paclitaxel resistance on ovarian cancer cells. OncoTargets Ther. 2019, 12, 3881-3891. [CrossRef] [PubMed] 
38. Giaccone, G.; Van Ark-Otte, J.; Rubio, G.J.; Gazdar, A.F.; Broxterman, H.J.; Dingemans, A.-M.C.; Flens, M.J.; Scheper, R.J.; Pinedo, H.M. MRP is frequently expressed in human lung-cancer cell lines, in non-small-cell lung cancer and in normal lung. Int. J. Cancer 1996, 66, 760-767. [CrossRef]

39. Wang, J.; Zhang, J.; Zhang, L.; Zhao, L.; Fan, S.; Yang, Z.; Gao, F.; Kong, Y.; Xiao, G.G.; Wang, Q. Expression of P-gp, MRP, LRP, GST-Pi and TopoII $\alpha$ and intrinsic resistance in human lung cancer cell lines. Oncol. Rep. 2011, 26, 1081-1089.

40. Gottesman, M.M.; Fojo, T.; Bates, S.E. Multidrug resistance in cancer: Role of ATP-dependent transporters. Nat. Rev. Cancer 2002, 2, 48-58. [CrossRef]

41. Kozovska, Z.; Gabrisova, V.; Kucerova, L. Colon cancer: Cancer stem cells markers, drug resistance and treatment. Biomed. Pharm. Biomed. Pharm. 2014, 68, 911-916. [CrossRef]

42. Fic, M.; Gomulkiewicz, A.; Grzegrzolka, J.; Podhorska-Okolow, M.; Zabel, M.; Dziegiel, P.; Jablonska, K. The impact of melatonin on colon cancer cells' resistance to doxorubicin in an in vitro study. Int. J. Mol. Sci. 2017, 18, 1396. [CrossRef] [PubMed]

43. Liu, K.; Song, J.; Yan, Y.; Zou, K.; Che, Y.; Wang, B.; Li, Z.; Yu, W.; Guo, W.; Zou, L.; et al. Melatonin increases the chemosensitivity of diffuse large B-cell lymphoma cells to epirubicin by inhibiting P-glycoprotein expression via the NF-kB pathway. Transl. Oncol. 2021, 14, 100876. [CrossRef]

44. Carocci, A.; Catalano, A.; Lovece, A.; Lentini, G.; Duranti, A.; Lucini, V.; Pannacci, M.; Scaglione, F.; Franchini, C. Design, synthesis, and pharmacological effects of structurally simple ligands for MT1 and MT2 melatonin receptors. Bioorg. Med. Chem. 2010, 18, 6496-6511. [CrossRef]

45. Kabra, R.; Chauhan, N.; Kumar, A.; Ingale, P.; Singh, S. Efflux pumps and antimicrobial resistance: Paradoxical components in systems genomics. Prog. Biophys. Mol. Biol. 2019, 141, 15-24. [CrossRef]

46. Teng, Q.X.; Luo, X.; Lei, Z.N.; Wang, J.Q.; Wurpel, J.; Qin, Z.; Yang, D.H. The multidrug resistance-reversing activity of a novel antimicrobial peptide. Cancers 2020, 12, 1963. [CrossRef]

47. Jackson, S.M.; Manolaridis, I.; Kowal, J.; Zechner, M.; Taylor, N.M.I.; Bause, M.; Bauer, S.; Bartholomaeus, R.; Bernhardt, G.; Koenig, B.; et al. Structural basis of small-molecule inhibition of human multidrug transporter ABCG2. Nat. Struct. Mol. Biol. 2018, 25, 333-340. [CrossRef] [PubMed]

48. Robey, R.W.; Pluchino, K.M.; Hall, M.D.; Fojo, A.T.; Bates, S.E.; Gottesman, M.M. Revisiting the role of ABC transporters in multidrug-resistant cancer. Nat. Rev. Cancer 2018, 18, 452-464. [CrossRef] [PubMed]

49. Wang, J.-Q.; Li, J.Y.; Teng, Q.-X.; Lei, Z.-N.; Ji, N.; Cui, Q.; Zeng, L.; Pan, Y.; Yang, D.-H.; Chen, Z.-S. Venetoclax, a BCL-2 inhibitor, enhances the efficacy of chemotherapeutic agents in wild-type ABCG2-overexpression-mediated MDR cancer cells. Cancers 2020, 12, 466. [CrossRef]

50. Puxeddu, M.; Shen, H.; Bai, R.; Coluccia, A.; Bufano, M.; Nalli, M.; Sebastiani, J.; Brancaccio, D.; Da Pozzo, E.; Tremolanti, C.; et al. Discovery of pyrrole derivatives for the treatment of glioblastoma and chronic myeloid leukemia. Eur. J. Med. Chem. 2021, 221, 113532. [CrossRef] [PubMed]

51. Catalano, A.; Iacopetta, D.; Sinicropi, M.S.; Franchini, C. Diarylureas as antitumor agents. Appl. Sci. 2021, 11, 374. [CrossRef]

52. Iacopetta, D.; Ceramella, J.; Catalano, A.; Saturnino, C.; Bonomo, M.G.; Franchini, C.; Sinicropi, M.S. Schiff bases: Interesting scaffolds with promising antitumoral properties. Appl. Sci. 2021, 11, 1877. [CrossRef]

53. Sirignano, E.; Saturnino, C.; Botta, A.; Sinicropi, M.S.; Caruso, A.; Pisano, A.; Lappano, R.; Maggiolini, M.; Longo, P. Synthesis, characterization and cytotoxic activity on breast cancer cells of new half-titanocene derivatives. Bioorg. Med. Chem. Lett. 2013, 23 , 3458-3462. [CrossRef]

54. Bruno, G.; Nicolò, F.; Schiavo, S.L.; Sinicropi, M.S.; Tresoldi, G. Synthesis and spectroscopic properties of di-2-pyridyl sulfide (dps) compounds. Crystal structure of $\left[\mathrm{Ru}(\mathrm{dps})_{2} \mathrm{Cl}_{2}\right.$ ]. J. Chem. Soc. Dalton Transact. 1995, 1, 17-24. [CrossRef]

55. Iacopetta, D.; Mariconda, A.; Saturnino, C.; Caruso, A.; Palma, G.; Ceramella, J.; Muia, N.; Perri, M.; Sinicropi, M.S.; Caroleo, M.C.; et al. Novel gold and silver carbene complexes exert antitumor effects triggering the reactive oxygen species dependent intrinsic apoptotic pathway. ChemMedChem 2017, 12, 2054-2065. [CrossRef]

56. Catalano, A.; Sinicropi, M.S.; Iacopetta, D.; Ceramella, J.; Mariconda, A.; Rosano, C.; Scali, E.; Saturnino, C.; Longo, P. A review on the advancements in the field of metal complexes with Schiff bases as antiproliferative agents. Appl. Sci. 2021, 11, 6027. [CrossRef]

57. Cui, Q.; Wang, J.Q.; Assaraf, Y.G.; Ren, L.; Gupta, P.; Wei, L.; Ashby, C.R., Jr.; Yang, D.-H.; Chen, Z.-S. Modulating ROS to overcome multidrug resistance in cancer. Drug Resist. Updat. 2018, 41, 1-25. [CrossRef]

58. Iacopetta, D.; Ceramella, J.; Rosano, C.; Mariconda, A.; Pellegrino, M.; Sirignano, M.; Saturnino, C.; Catalano, A.; Aquaro, S.; Longo, P.; et al. N-Heterocyclic carbene-gold(I) complexes targeting actin polymerization. Appl. Sci. 2021, 11, 5626. [CrossRef]

59. Perillo, B.; Di Donato, M.; Pezone, A.; Di Zazzo, E.; Giovannelli, P.; Galasso, G.; Castoria, G.; Migliaccio, A. ROS in cancer therapy: The bright side of the moon. Exp. Mol. Med. 2020, 52, 192-203. [CrossRef] [PubMed]

60. Tundis, R.; Iacopetta, D.; Sinicropi, M.S.; Bonesi, M.; Leporini, M.; Passalacqua, N.G.; Ceramella, J.; Menichini, F.; Loizzo, M.R. Assessment of antioxidant, antitumor and pro-apoptotic e_ects of Salvia fruticosa Mill. subsp. thomasii (Lacaita) Brullo, Guglielmo, Pavone \& Terrasi (Lamiaceae). Food Chem. Toxicol. Int. J. Publ. Br. Ind. Biol. Res. Assoc. 2017, 106, 155-164.

61. Fazio, A.; Iacopetta, D.; La Torre, C.; Ceramella, J.; Muia, N.; Catalano, A.; Carocci, A.; Sinicropi, M.S. Finding solutions for agricultural wastes: Antioxidant and antitumor properties of pomegranate Akko peel extracts and beta-glucan recovery. Food Funct. 2018, 9, 6618-6631. [CrossRef]

62. Alamolhodaei, N.S.; Tsatsakis, A.M.; Ramezani, M.; Hayes, A.W.; Karimi, G. Resveratrol as MDR reversion molecule in breast cancer: An overview. Food Chem. Toxicol. 2017, 103, 223-232. [CrossRef] 
63. Chimento, A.; Santarsiero, A.; Iacopetta, D.; Ceramella, J.; De Luca, A.; Infantino, V.; Parisi, O.; Avena, P.; Bonomo, M.; Saturnino, C.; et al. A phenylacetamide resveratrol derivative exerts inhibitory effects on breast cancer cell growth. Int. J. Mol. Sci. 2021, 22, 5255. [CrossRef]

64. Ganley, I.G.; Wong, P.M.; Gammoh, N.; Jiang, X. Distinct autophagosomal-lysosomal fusion mechanism revealed by thapsigargininduced autophagy arrest. Mol. Cell 2011, 42, 731-743. [CrossRef] [PubMed]

65. Li, Y.-J.; Lei, Y.-H.; Yao, N.; Wang, C.-R.; Hu, N.; Ye, W.-C.; Zhang, D.-M.; Chen, Z.-S. Autophagy and multidrug resistance in cancer. Chin. J. Cancer 2017, 36, 52. [CrossRef] [PubMed]

66. Grigoreva, T.; Romanova, A.; Sagaidak, A.; Vorona, S.; Novikova, D.; Tribulovich, V. Mdm2 inhibitors as a platform for the design of P-glycoprotein inhibitors. Bioorg. Med. Chem. Lett. 2020, 30, 127424. [CrossRef]

67. Garcia, E.; Ly, N.; Diep, J.K.; Rao, G.G. Moving from point-based analysis to systems-based modeling: Integration of knowledge to address antimicrobial resistance against MDR bacteria. Clin. Pharmacol. Ther. 2021, 110, 1196-1206. [CrossRef]

68. Reygaert, W.C. An overview of the antimicrobial resistance mechanisms of bacteria. AIMS Microbiol. 2018, 4, 482-501. [CrossRef]

69. Chen, M.; Zhou, D.; Xu, G.; Xu, Z. The Prevalence of MDR non-fermenting Gram negative bacteria and their chemotherapy. Front. Microbiol. 2021, 12, 664336. [CrossRef]

70. Pozzi, C.; Ferrari, S.; Cortesi, D.; Luciani, R.; Stroud, R.M.; Catalano, A.; Costi, M.P.; Mangani, S. The structure of Enterococcus faecalis thymidylate synthase provides clues about folate bacterial metabolism. Acta Crystallogr. D Biol. Crystallogr. 2012, 68, 1232-1241. [CrossRef]

71. Iacopetta, D.; Carrisi, C.; De Filippis, G.; Calcagnile, V.M.; Cappello, A.R.; Chimento, A.; Curcio, R.; Santoro, A.; Vozza, A.; Dolce, V.; et al. The biochemical properties of the mitochondrial thiamine pyrophosphate carrier from Drosophila melanogaster. FEBS J. 2010, 277, 1172-1181. [CrossRef] [PubMed]

72. Carrisi, C.; Madeo, M.; Morciano, P.; Dolce, V.; Cenci, G.; Cappello, A.R.; Mazzeo, G.; Iacopetta, D.; Capobianco, L. Identification of the Drosophila melanogaster mitochondrial citrate carrier: Bacterial expression, reconstitution, functional characterization and developmental distribution. J. Biochem. 2008, 144, 389-392. [CrossRef]

73. Parisi, O.I.; Fiorillo, M.; Caruso, A.; Cappello, A.R.; Saturnino, C.; Puoci, F.; Panno, A.; Dolce, V.; El-Kashef, H.; Sinicropi, M.S. Enhanced cellular uptake by "pharmaceutically oriented devices" of new simplified analogs of Linezolid with antimicrobial activity. Int. J. Pharm. 2014, 461, 163-170. [CrossRef] [PubMed]

74. Catalano, A.; Iacopetta, D.; Rosato, A.; Salvagno, L.; Ceramella, J.; Longo, F.; Sinicropi, M.S.; Franchini, C. Searching for small molecules as antibacterials: Non-cytotoxic diarylureas analogues of triclocarban. Antibiotics 2021, 10, 204. [CrossRef]

75. Catalano, A.; Rosato, A.; Salvagno, L.; Iacopetta, D.; Ceramella, J.; Fracchiolla, G.; Sinicropi, M.S.; Franchini, C. Benzothiazolecontaining analogues of triclocarban with potent antibacterial activity. Antibiotics 2021, 10, 803. [CrossRef] [PubMed]

76. Rosato, A.; Catalano, A.; Carocci, A.; Carrieri, A.; Carone, A.; Caggiano, G.; Franchini, C.; Corbo, F.; Montagna, M.T. In vitro interactions between anidulafungin and nonsteroidal anti-inflammatory drugs on biofilms of Candida spp. Bioorg. Med. Chem. 2016, 24, 1002-1005. [CrossRef]

77. Catalano, A.; Iacopetta, D.; Pellegrino, M.; Aquaro, S.; Franchini, C.; Sinicropi, M. Diarylureas: Repositioning from antitumor to antimicrobials or multi-target agents against new pandemics. Antibiotics 2021, 10, 92. [CrossRef]

78. Divyashree, M.; Mani, M.K.; Reddy, D.; Kumavath, R.; Ghosh, P.; Azevedo, V.; Barh, D. Clinical Applications of Antimicrobial Peptides (AMPs): Where Do We Stand Now? Protein Pept. Lett. 2020, 27, 120-134. [CrossRef]

79. Parkins, M.D.; Somayaji, R.; Waters, V.J. Epidemiology, biology, and impact of clonal pseudomonas aeruginosa infections in cystic fibrosis. Clin. Microbiol. Rev. 2018, 31, e00019-18. [CrossRef]

80. Yin, Q.; Wu, S.; Wu, L.; Wang, Z.; Mu, Y.; Zhang, R.; Dong, C.; Zhou, B.; Zhao, B.; Zheng, J.; et al. A novel in silico antimicrobial peptide DP7 combats MDR Pseudomonas aeruginosa and related biofilm infections. J. Antimicrob. Chemother. 2020, 75, 3248-3259. [CrossRef]

81. Hoiby, N.; Bjarnsholt, T.; Givskov, M.; Molin, S.; Ciofy, O. Antibiotic resistance of bacterial biofilms. Int. J. Antimicrob. Agents 2010, 35, 322-332. [CrossRef]

82. Fernández-Martínez, M.; González-Rico, C.; Gozalo-Margüello, M.; Marco, F.; Gracia-Ahufinger, I.; Aranzamendi, M.; SánchezDíaz, A.M.; Vicente-Rangel, T.; Chaves, F.; Montes, J.C.; et al. Molecular characterization of multidrug resistant Enterobacterales strains isolated from liver and kidney transplant recipients in Spain. Sci. Rep. 2021, 11, 1-9.

83. Brussow, H. Phage therapy for the treatment of human intestinal bacterial infections: Soon to be a reality? Exp. Rev. Gastroenterol. Hepatol. 2017, 11, 785-788. [CrossRef] [PubMed]

84. Schooley, R.T.; Biswas, B.; Gill, J.J.; Hernandez-Morales, A.; Lancaster, J.; Lessor, L.; Barr, J.J.; Reed, S.L.; Rohwer, F.; Benier, S.; et al. Development and use of personalized bacteriophage-based therapeutic cocktails to treat a patient with a disseminated resistant Acinetobacter baumannii infection. Antimicrob. Agents Chemother. 2017, 61, e00954-17. [CrossRef]

85. Agniswamy, J.; Kneller, D.W.; Ghosh, A.K.; Weber, I.T. Novel HIV PR inhibitors with C4-substituted bis-THF and bis-fluorobenzyl target the two active site mutations of highly drug resistant mutant PR(S17). Biochem. Biophys. Res. Commun. 2021, 566, 30-35. [CrossRef]

86. Chan, B.K.; Sistrom, M.; Wertz, J.E.; Kortright, K.E.; Narayan, D.; Turner, P.E. Phage selection restores antibiotic sensitivity in MDR Pseudomonas aeruginosa. Sci. Rep. 2016, 6, 26717. [CrossRef] 
87. Keating, C.L.; Zuckerman, J.B.; Singh, P.K.; McKevitt, M.; Gurtovaya, O.; Bresnik, M.; Marshall, B.C.; Saiman, L.; Group, C.-A.S. Pseudomonas aeruginosa susceptibility patterns and associated clinical outcomes in people with cystic fibrosis following approval of aztreonam lysine for inhalation. Antimicrob. Agents Chemother. 2020, 65, e02327-20. [CrossRef] [PubMed]

88. Vaillancourt, M.; Limsuwannarot, S.P.; Bresee, C.; Poopalarajah, R.; Jorth, P. Pseudomonas aeruginosa mexR and mexEF Antibiotic Efflux Pump Variants Exhibit Increased Virulence. Antibiotics 2021, 10, 1164. [CrossRef]

89. Papadimitriou-Olivgeris, M.; Bartzavali, C.; Georgakopoulou, A.; Kolonitsiou, F.; Papamichail, C.; Spiliopoulou, I.; Christofidou, M.; Fligou, F.; Marangos, M. Mortality of Pandrug-Resistant Klebsiella pneumoniae Bloodstream Infections in Critically Ill Patients: A Retrospective Cohort of 115 Episodes. Antibiotics 2021, 10, 76. [CrossRef]

90. Bastos, M.L.; Cosme, L.B.; Fregona, G.; do Prado, T.N.; Bertolde, A.I.; Zandonade, E.; Sanchez, M.N.; Dalcolmo, M.P.; Kritski, A.; Trajman, A.; et al. Treatment outcomes of MDR-tuberculosis patients in Brazil: A retrospective cohort analysis. BMC Infect. Dis. 2017, 17, 718. [CrossRef]

91. Sturkenboom, M.G.G.; Simbar, N.; Akkerman, O.W.; Ghimire, S.; Bolhuis, M.S.; Al_enaar, J.W.C. Amikacin dosing for MDR tuberculosis: A systematic review to establish or revise the current recommended dose for tuberculosis treatment. Clin. Infect. Dis. 2018, 67 (Suppl. 3), S303-S307. [CrossRef] [PubMed]

92. Hwang, H.; Kang, H.; Kwon, Y.S.; Jeon, D.; Shim, T.S.; Yim, J.J. Outcomes of multidrug-resistant tuberculosis treated with bedaquiline or delamanid. Clin. Infect. Dis. 2021. [CrossRef] [PubMed]

93. WHO. Multidrug-Resistant Tuberculosis (MDR-TB); WHO: Geneva, Switzerland, 2013.

94. Migliori, G.B.; Tiberi, S.; Zumla, A.; Petersen, E.; Chakaya, J.M.; Wejse, C.; Muñoz Torrico, M.; Duarte, R.; Affenaar, J.W.; Schaaf, H.S.; et al. MDR/XDR-TB management of patients and contacts: Challenges facing the new decade. The 2020 clinical update by the Global Tuberculosis Network. Int. J. Infect. Dis. 2020, 92, S15-S25. [CrossRef] [PubMed]

95. Kumari, S.; Kumar, M.; Gaur, N.A.; Prasad, R. Multiple roles of ABC transporters in yeast. Fungal Genet. Biol. 2021, 150, 103550. [CrossRef]

96. Prasad, R.; Goffeau, A. Yeast ATP-binding cassette transporters conferring multidrug resistance. Annu. Rev. Microbiol. 2012, 66, 39-63. [CrossRef] [PubMed]

97. Khunweeraphong, N.; Kuchler, K. Multidrug resistance in mammals and fungi-From MDR to PDR: A rocky road from atomic structures to transport mechanisms. Int. J. Mol. Sci. 2021, 22, 4806. [CrossRef] [PubMed]

98. Moreno, A.; Banerjee, A.; Prasad, R.; Falson, P. PDR-like ABC systems in pathogenic fungi. Res. Microbiol. 2019, 170, 417-425. [CrossRef] [PubMed]

99. Verweij, P.E.; Chowdhary, A.; Melchers, W.J.; Meis, J.F. Azole resistance in Aspergillus fumigatus: Can we retain the clinical use of mold-active antifungal azoles? Clin. Infect. Dis. 2016, 62, 362-368. [CrossRef] [PubMed]

100. Chowdhary, A.; Sharma, C.; Meis, J.F. Candida auris: A rapidly emerging cause of hospital-acquired multidrug-resistant fungal infections globally. PLoS Pathog. 2017, 13, e1006290. [CrossRef] [PubMed]

101. Banerjee, A.; Moreno, A.; Khan, M.F.; Nair, R.; Sharma, S.; Sen, S.; Mondal, A.K.; Pata, J.; Orelle, C.; Falson, P.; et al. Cdr1p highlights the role of the non-hydrolytic ATP-binding site in driving drug translocation in asymmetric ABC pumps. Biochim. Biophys. Acta Biomembr. 2020, 1862, 183131. [CrossRef]

102. Burmeister, A.R. Horizontal gene transfer. Evol. Med. Public Health 2015, 2015, 193-194. [CrossRef] [PubMed]

103. Lerminiaux, N.A.; Cameron, A.D.S. Horizontal transfer of antibiotic resistance genes in clinical environments. Can. J. Microbiol. 2019, 65, 34-44. [CrossRef]

104. Musso, M.; Mosti, S.; Gualano, G.; Mencarini, P.; Urso, R.; Ghirga, P.; Del Nonno, F.; Goletti, D.; Palmieri, F. Hepatitis C virus infection: A challenge in the complex management of two cases of multidrug-resistant tuberculosis. BMC Infect. Dis. 2019, 19, 882. [CrossRef]

105. Brust, J.C.; Shah, N.S.; Mlisana, K.; Moodley, P.; Allana, S.; Campbell, A.; Gandhi, N.R. Improved survival and cure rates with concurrent treatment for multidrug-resistant tuberculosis-human immunodeficiency virus coinfection in South Africa. Clin. Infect. Dis. 2017, 66, 1246-1253. [CrossRef]

106. McKeegan, K.S.; Borges-Walmsley, M.I.; Walmsley, A.R. Microbial and viral drug resistance mechanisms. Trends Microbiol. 2002, 10, s8-s14. [CrossRef]

107. Richman, D.D. Drug resistance in viruses. Trends Microbiol. 1994, 2, 401-407. [CrossRef]

108. Van der Vries, E.; Stelma, F.F.; Boucher, C.A. Emergence of a multidrug- resistant pandemic influenza A (H1N1) virus. N. Engl. J. Med. 2010, 363, 1381-1382. [CrossRef] [PubMed]

109. Lawrence, J.; Mayers, D.L.; Hullsiek, K.H.; Collins, G.; Abrams, D.I.; Reisler, R.B.; Crane, L.R.; Schmetter, B.S.; Dionne, T.J.; Saldanha, J.M.; et al. Structured treatment interruption in patients with multidrug-resistant human immunodeficiency virus. $N$. Engl. J. Med. 2003, 349, 837-846. [CrossRef]

110. Colby, D.J.; Kroon, E.; Sacdalan, C.; Gandhi, M.; Grant, R.M.; Phanuphak, P.; Ananworanich, J.; Robb, M.L.; Phanuphak, N. Acquisition of multidrug-resistant human immunodeficiency virus type 1 infection in a patient taking preexposure prophylaxis. Clin. Infect. Dis. 2018, 67, 962-964. [CrossRef]

111. Saladini, F.; Giannini, A.; Giammarino, F.; Maggiolo, F.; Vichi, F.; Corbelli, G.M.; Galli, A.; Bigoloni, A.; Poli, A.; Santoro, M.M.; et al. In vitro susceptibility to fostemsavir is not affected by long-term exposure to antiviral therapy in MDR HIV-1-infected patients. J. Antimicrob. Chemother. 2020, 75, 2547-2553. [CrossRef] 
112. Caruso, A.; Ceramella, J.; Iacopetta, D.; Saturnino, C.; Mauro, M.V.; Bruno, R.; Aquaro, S.; Sinicropi, M.S. Carbazole derivatives as antiviral agents: An overview. Molecules 2019, 24, 1912. [CrossRef]

113. Pelfrene, E.; Botgros, R.; Cavaleri, M. Antimicrobial multidrug resistance in the era of COVID-19: A forgotten plight? Antimicrob. Resist. Infect. Control 2021, 10, 21. [CrossRef]

114. Bork, J.T.; Leekha, S.; Claeys, K.; Seung, H.; Tripoli, M.; Amoroso, A.; Heil, E.L. Change in hospital antibiotic use and acquisition of multidrug-resistant gram-negative organisms after the onset of coronavirus disease. Infect. Control Hosp. Epidemiol. 2021, 42, 1115-1117. [CrossRef]

115. Lobie, T.A.; Roba, A.A.; Booth, J.A.; Kristiansen, K.I.; Aseffa, A.; Skarstad, K.; Bjørås, M. Antimicrobial resistance: A challenge awaiting the post-COVID-19 era. Int. J. Infect. Dis. 2021, 111, 322-325. [CrossRef]

116. Ukuhor, H.O. The Interrelationships between Antimicrobial Resistance, COVID-19, Past, and Future Pandemics. J. Infect. Public Health 2021, 14, 53-60. [CrossRef] [PubMed]

117. Knight, G.M.; Glover, R.E.; McQuaid, C.F.; Olaru, I.D.; Gallandat, K.; Leclerc, Q.J.; Fuller, N.M.; Willcocks, S.J.; Hasan, R.; van Kleef, E.; et al. Antimicrobial resistance and COVID-19: Intersections and implications. Elife 2021, 10, e64139. [CrossRef]

118. Bentivegna, E.; Luciani, M.; Arcari, L.; Santino, I.; Simmaco, M.; Martelletti, P. Reduction of multidrug-resistant (MDR) bacterial infections during the COVID-19 pandemic: A retrospective study. Int. J. Environ. Res. Public Health 2021, 18, 1003. [CrossRef]

119. Fulfager, A.D.; Yadav, K.S. Understanding the implications of co-delivering therapeutic agents in a nanocarrier to combat multidrug resistance (MDR) in breast cancer. J. Drug Deliv. Sci. Technol. 2021, 62, 102405. [CrossRef]

120. Ahmad, J.; Akhter, S.; Ahmed Khan, M.; Wahajuddin, M.; H Greig, N.; Amjad Kamal, M.; Midoux, P.; Pichon, C. Engineered nanoparticles against MDR in cancer: The state of the art and its prospective. Curr. Pharm. Des. 2016, 22, 4360-4373. [CrossRef]

121. Arvizo, R.; Bhattacharya, R.; Mukherjee, P. Gold nanoparticles: Opportunities and challenges in nanomedicine. Expert Opin. Drug Deliv. 2010, 7, 753-763. [CrossRef]

122. Veronese, F.M.; Mero, A. The impact of PEGylation on biological therapies. BioDrugs 2008, 22, 315-329. [CrossRef] [PubMed]

123. Cheng, J.; Gu, Y.-J.; Cheng, S.H.; Wong, W.-T. Surface functionalized gold nanoparticles for drug delivery. J. Biomed. Nanotechnol. 2013, 9, 1362-1369. [CrossRef] [PubMed]

124. Ali, H.S.; El-Haj, B.M.; Saifullah, S.; Kawish, M. Gold Nanoparticles in Cancer Diagnosis and Therapy; Elsevier: Amsterdam, The Netherlands, 2019; ISBN 9780128169605.

125. Jiang, Y.; Wang, Z.; Duan, W.; Liu, L.; Si, M.; Chen, X.; Fang, C.J. The critical size of gold nanoparticles for overcoming P-gp mediated multidrug resistance. Nanoscale 2020, 12, 16451-16461. [CrossRef] [PubMed]

126. Baptista, P.V.; McCusker, M.P.; Carvalho, A.; Ferreira, D.A.; Mohan, N.; Martins, M.; Fernandes, A.R. Nano-strategies to fight multidrug resistant bacteria-“"A battle of the titans". Front. Microbiol. 2018, 9, 1441. [CrossRef] [PubMed]

127. Pelgrift, R.Y.; Friedman, A.J. Nanotechnology as a therapeutic tool to combat microbial resistance. Adv. Drug Deliv. Rev. 2013, 65, 1803-1815. [CrossRef] [PubMed]

128. Naskar, A.; Kim, K.-S. Nanomaterials as delivery vehicles and components of new strategies to combat bacterial infections: Advantages and limitations. Microorganisms 2019, 7, 356. [CrossRef] [PubMed]

129. Vanamala, K.; Tatiparti, K.; Bhise, K.; Sau, S.; Scheetz, M.H.; Rybak, M.J.; Andes, D.; Iyer, A.K. Novel approaches for the treatment of methicillin-resistant Staphylococcus aureus: Using nanoparticles to overcome multidrug resistance. Drug Discov. Today 2020, 26, 31-43. [CrossRef]

130. Saravanan, M.; Duche, K.; Asmelash, T.; Gebreyesus, A.; Negash, L.; Tesfay, A.; Hailekiros, H.; Niguse, S.; Gopinath, V.; Barik, S. "Nano-Biomaterials"-A new approach concerning multi-drug resistant tuberculosis (MDR-TB). Pharm. Nanotechnol. 2015, 3, 5-18. [CrossRef]

131. Song, X.; Liu, P.; Liu, X.; Wang, Y.; Wei, H.; Zhang, J.; Yu, L.; Yan, X.; He, Z. Dealing with MDR bacteria and biofilm in the post-antibiotic era: Application of antimicrobial peptides-based nano-formulation. Mater. Sci. Eng. C Mater. Biol. Appl. 2021, 128, 112318. [CrossRef] [PubMed] 